\title{
Survey of artemisinin production by diverse Artemisia species in northern Pakistan
}

\author{
Abdul Mannan 1,3*, Ibrar Ahmed ${ }^{1,4}$, Waheed Arshad1', Muhammad F Asim¹, Rizwana A Qureshi², Izhar Hussain ${ }^{3}$, \\ Bushra Mirza ${ }^{* *}$
}

\begin{abstract}
Background: Artemisinin is the current drug of choice for treatment of malaria and a number of other diseases. It is obtained from the annual herb, Artemisia annua and some microbial sources by genetic engineering. There is a great concern that the artemisinin production at current rate will not meet the increasing demand by the pharmaceutical industry, so looking for additional sources is imperative.

Methods: In current study, artemisinin concentration was analysed and compared in the flowers, leaves, roots and stems of Artemisia annua and 14 other Artemisia species including two varieties each for Artemisia roxburghiana and Artemisia dracunculus using high performance liquid chromatography (HPLC).

Results: The highest artemisinin concentration was detected in the leaves $(0.44 \pm 0.03 \%)$ and flowers $(0.42 \pm$ $0.03 \%)$ of $A$. annua, followed by the flowers $(0.34 \pm .02 \%)$ of $A$. bushriences and leaves $(0.27 \pm 0 \%)$ of $A$. dracunculus var dracunculus. The average concentration of artemisinin varied in the order of flowers $>$ leaves $>$ stems $>$ roots.

Conclusion: This study identifies twelve novel plant sources of artemisinin, which may be helpful for pharmaceutical production of artemisinin. This is the first report of quantitative comparison of artemisinin among a large number of Artemisia species.
\end{abstract}

\section{Background}

Despite advances in medical sciences, malaria is still a global health problem causing a death toll of approximately one million per annum [1]. More than one billion people live in areas with high malarial risk [2]. There were 243 million cases of malaria in 2008, causing 863,000 deaths, mostly among children in Africa [3], where malaria accounts for $20 \%$ of all childhood deaths [4]. This has resulted in enormous pressure on economy of the countries with high disease rates, causing as much as $1.3 \%$ reduction in GDP, up to $40 \%$ of public health expenditures, $30 \%$ to $50 \%$ of inpatient hospital admission, and $60 \%$ outpatient visits to health clinics [4]. Artemisinin combination therapy (ACT) is currently the most effective means to treat and reduce the transmission rate of malaria [5]. The World Health Organization (WHO) recommends ACT as first-line treatment for uncomplicated malaria caused by Plasmodium falciparum [6]. Artemisinin has

\footnotetext{
* Correspondence: abdulmannan_ka@yahoo.com; bushra_dr@yahoo.com ${ }^{1}$ Department of Biochemistry, Quaid-i-Azam University, Islamabad, Pakistan Full list of author information is available at the end of the article
}

also been demonstrated to be effective against some other parasites including Leishmania [7], Schistosoma [8], Toxoplasma [9] and Trypanomosa [10]. It has also antiviral activities [11] and can be used in treatment of hepatitis B [12] and a range of cancer cell lines, including breast cancer, human leukaemia, colon, and small-cell lung carcinomas [13]. Furthermore, artemisinin may be especially effective in treating drug resistant cancers $[14,15]$. Another important role of artemisinin is its allelopathic activity; it is a potent plant inhibitor with potential as a natural herbicide [16]. Artemisinin has been considered as a relatively safe drug with no obvious adverse reactions or serious side effects, even for pregnant women [17]. A recent study [18], however, outlines potential toxic effects of artemisinin when used for long periods and offers suggestions for safe use.

For a pharmaceutical industry supplying over 100 million treatments per annum [2], there is a growing concern that the artemisinin supply chain will be unable to meet future requirements $[19,20]$. Access of patients to artemisininbased combination therapy was inadequate in all countries surveyed during 2007 and 2008 [3]. Microbial-based 
systems to synthesize artemisinin precursors for chemical conversion have been reported [21-24]. However, agricultural production is likely to remain the primary source of supply [19]. Artemisinin is a sesquiterpenoid, produced in glandular trichomes of Artemisia annua [25]. Artemisia annua, a member of the Asteraceae family, is endemic to China and has been used there for over two thousand years to treat malaria [26]. Other species of Artemisia have been screened as potential new sources for agricultural production. Artemisinin has been reported in Artemisia apiacea and Artemisia lancea [26], Artemisia cina [27] and in aerial parts of Artemisia sieberi [28]. Presence of artemisinin has also been reported in Artemisia absinthium [29], Artemisia dubia and Artemisia indica [30] growing in Pakistan.

Twenty five species of Artemisia are known to exist in Pakistan [31] and most of them are found in northern frontier regions, in foothills and ranges of the Karakoram, Himalaya and Hindu Kush mountains, in districts Gilgit, Chitral, Skardu, Swat, Rawalpindi, Abbottabad and Kashmir (personal observations). Many of these species have a long history of use as folk therapeutic plants [32]. Purpose of the current study was to explore potential new sources of artemisinin, and compare artemisinin concentration in different parts of various Artemisia species found in northern areas of Pakistan. The study reports 12 new potential sources of artemisinin identified first time as well as and their artemisinin concentration compared in flowers, leaves, stems and roots.

\section{Methods}

In total, fifteen indigenous Artemisia species including two varieties each for two species (Artemisia roxburghiana and Artemisia dracunculus; Figure 1) were collected in summer 2007 from various Himalayan, Karakoram and Hindu Kush ranges of Northern Pakistan (Figure 2). All seventeen species [33] were harvested and collected at flowering stage. Their population was found dense in the locations mentioned in Table 1 . The complete distribution patterns of individual species will be covered elsewhere. These species were identified in Herbarium of Islamabad, Pakistan, by following the description in Flora of Pakistan [31] and comparing with already identified herbarium sheets of same Artemisia species preserved in the herbarium. These species were given the herbarium numbers and were deposited in the herbarium collection. These Artemisia species were screened to measure the artemisinin concentration in their four parts including flowers, leaves, stems and roots.

For analysis and quantification of artemisinin, five plants per Artemisia species were harvested at any given location. Artemisinin was analysed by HPLC in triplicate from each part of each of these five plants (i.e. a total of 15 samples for each individual part per species). Artemisinin was extracted from different parts i.e. flowers, leaves, stems and roots of all Artemisia species following a reported methodology [34] with some modifications as follows: one gram each of fresh floral, leaf, stem and root parts of each Artemisia species was taken and placed in oven at $60^{\circ} \mathrm{C}$ for three days. Floral parts included complete inflorescence, leaves included whole leaves with short stalks inclusive and plucked from upper surface of the plants, which were maximally exposed to light, stems included green slender branches connected to the leaves, while roots comprised mostly of parts close to the root tips. Their dry weights were measured; the tissues were grinded with mortar and pestle and put in $5 \mathrm{ml}$ of HPLC grade toluene (Sigma) to make a homogenous mixture. These mixtures were placed in sonicator (Elma ${ }^{\mathrm{TM}}$, Germany) for $30 \mathrm{~min}$. During sonication, artemisinin was released into toluene, which was separated from cellular debris by centrifugation at $2000 \times \mathrm{g}$ and $-8^{\circ} \mathrm{C}$ for 20 minutes (Eppendorf centrifuge, model 5810R). Supernatant was decanted and saved in dram vials. Pellets were re-suspended in $5 \mathrm{ml}$ toluene, vortexed, sonicated again for 30 minutes, centrifuged and decanted as above. Pellets were discarded, both supernatants were pooled; extracts for each replicate were air dried before storing at $-20^{\circ} \mathrm{C}$ for further analysis.

The dried extracts and dried dilutions of standard artemisinin were converted to Q260 derivative of artemisinin as follows: each extract was solubilized in $400 \mu \mathrm{l}$ of methanol (Sigma) and $1600 \mu \mathrm{l}$ of $0.2 \%(\mathrm{w} / \mathrm{v}) \mathrm{NaOH}$; then hydrolyzed for $45 \mathrm{~min}$ at $50^{\circ} \mathrm{C}$. The reaction was stopped by adding $1600 \mu \mathrm{l}$ of $0.2 \mathrm{M}$ acetic acid (Merck) and placing the test tube on ice. To make a final volume of $4 \mathrm{ml}$, $400 \mu \mathrm{l}$ of methanol was added. Samples at this stage contained Q260 derivative of artemisinin, and were filtered through $0.45 \mu \mathrm{m}$ filter before injecting into HPLC for analysis. All samples were hydrolyzed just before use.

For HPLC analysis, mobile phase was prepared by combining 45\% (v/v) methanol (Sigma) and 55\% $0.01 \mathrm{M}$ sodium phosphate buffer ( $\mathrm{pH} 7.0)$. All samples were analysed with a Zorbax SB C18 column $(150 \times 4.6 \mathrm{~mm} \times$ $5 \mu \mathrm{m}$; Agilent Technologies USA). Flow of the mobile phase through column (stationary phase) was optimized to $1 \mathrm{ml} / \mathrm{min}$. Artemisinin was detected by using Diode Array Detector (G1315B-DAD) at $260 \mathrm{~nm}$ absorbance and its retention time was $12 \mathrm{~min}$. Artemisinin concentration was calculated as a percentage of dry weight, average values were calculated for each part, and data were analysed using ANOVA and LSD.

\section{Results}

Amongst all Artemisia species studied, the highest artemisinin concentration was found in leaves of Artemisia annua $(0.44 \pm 0.03 \%)$, followed by flowers of 

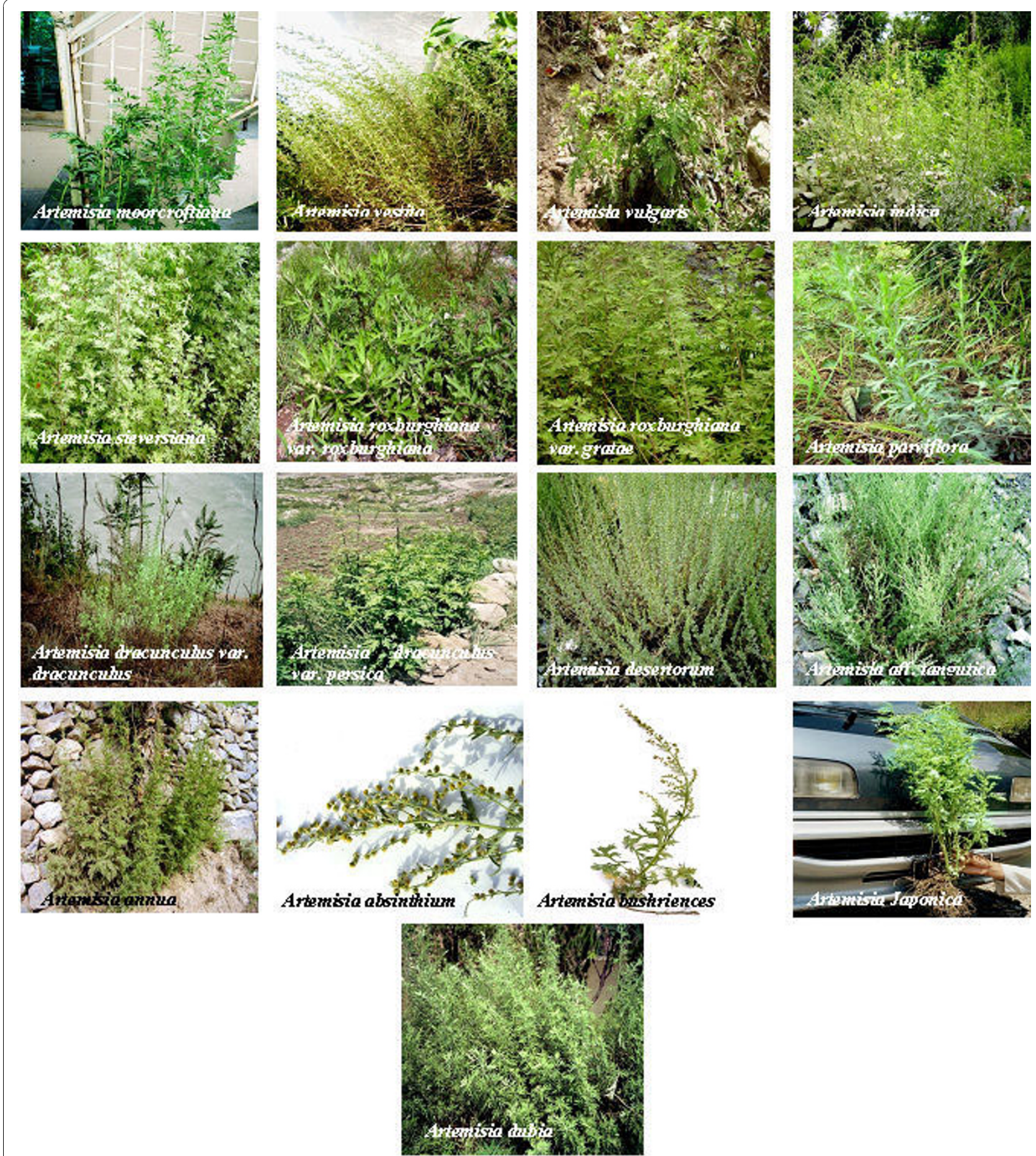

Figure 1 Field pictures of seventeen Artemisia species at the time of collection.

A. annua (0.42 $\pm 0.03 \%)$, flowers of Artemisia bushriences $(0.34 \pm 0.02 \%)$, and leaves of Artemisia dracunculus var dracunculus $(0.27 \pm 0 \%)$, as shown in Figure 3 \& 4.

Artemisia апnиa showed highest and almost equal artemisinin concentration in flowers and leaves. Equal levels of artemisinin were also detected in the Artemisia vulgaris and Artemisia aff tangutica leaves and flowers. Ten species (Artemisia moorcroftiana, Artemisia vestita, Artemisia indica, Artemisia sieversiana, Artemisia roxburghiana var roxburghiana, Artemisia parviflora, Artemisia absinthium, Artemisia bushriences, Artemisia 


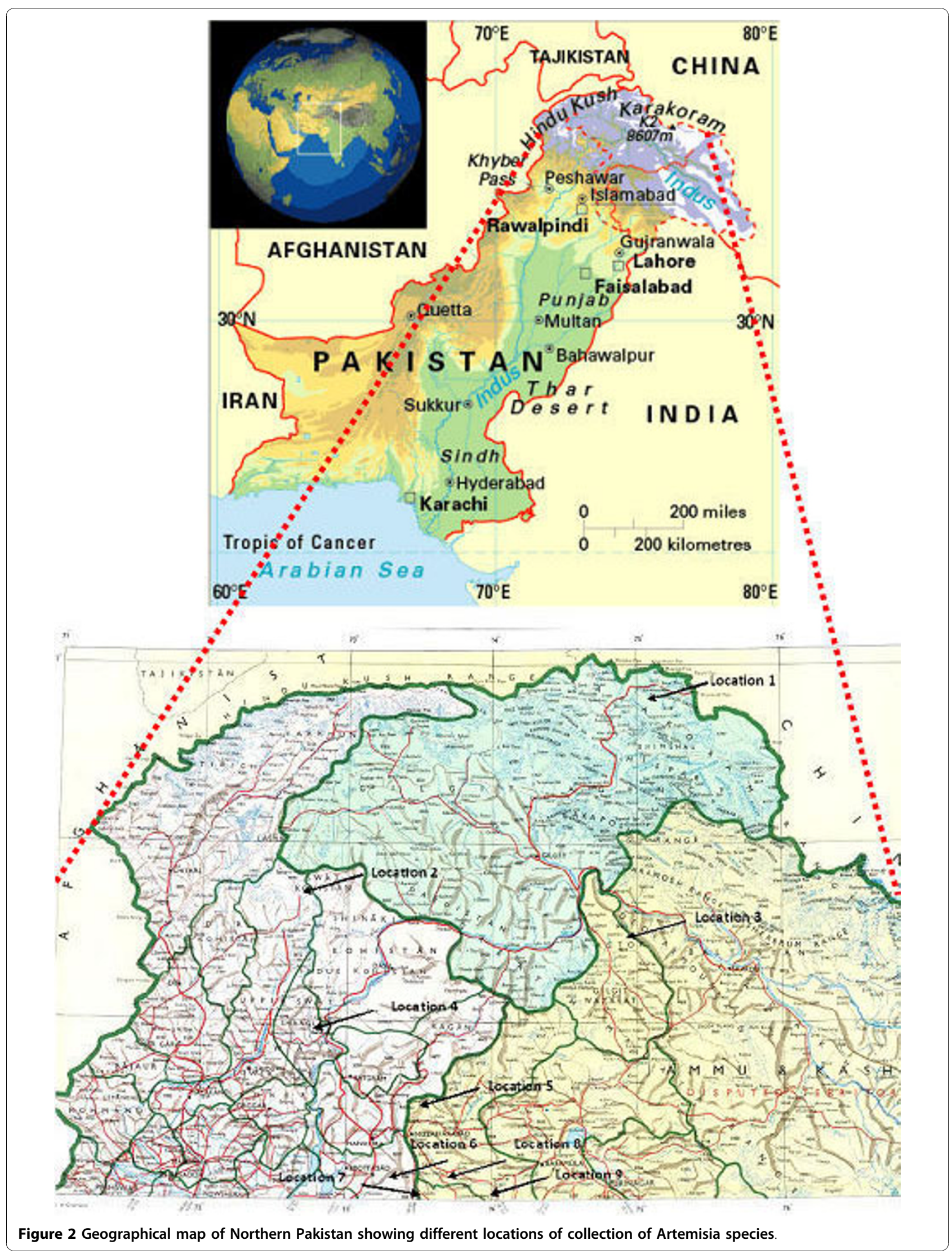


Table 1 Artemisia species collected at flowering stage from different hilly locations of Northern Pakistan

\begin{tabular}{|c|c|c|c|c|}
\hline S. No. & Species & Location No. & Location name & Sampling Point \\
\hline 1 & A. moorcroftiana & 2 & Kalam, Swat & Saeed Abad \\
\hline 2 & A. vestita & 6 & Galyat & Donga Gali \\
\hline 3 & A. vulgaris & 2 & Kalam, Swat & Gatal \\
\hline 4 & A. indica & 4 & Shangla, Swat & Topseen \\
\hline 5 & A. sieversiana & 1 & Soost, Northern Areas & Aaeen Abad \\
\hline 6 & A. roxburghiana var roxburghiana & 8 & Rawalakot, Azad Kashmir & Mujahid Abad \\
\hline 7 & A. roxburghiana var gratae & 7 & Murree, Rawalpindi & Bhurban \\
\hline 8 & A. parviflora & 8 & Rawalakot, Azad Kashmir & Tararh Khal \\
\hline 9 & A. dracunculus var dracunculus & 9 & Abbass Pur, Azad Kashmir & Abbass Pur \\
\hline 10 & A. dracunculus var persica & 8 & Rawalakot, Azad Kashmir & Rawalakot \\
\hline 11 & A. desertorum & 4 & Shangla, Swat & Shangla Hill Top \\
\hline 12 & A. aff. Tangutica & 5 & Shugran, Mansehra & Payee Base \\
\hline 13 & A. annua & 3 & Astore, Northern Areas & Kachar Abad \\
\hline 14 & A. absinthium & 3 & Astore, Northern Areas & Chilam Choki \\
\hline 15 & A. bushriences & 1 & Soost, Northern Areas & Aaeen Abad \\
\hline 16 & A. japonica & 6 & Galyat & Donga Gali \\
\hline 17 & A. dubia & 6 & Galyat & Donga Gali \\
\hline
\end{tabular}

japonica and Artemisia dubia) showed higher artemisinin concentration in their flowers, while two species (Artemisia roxburghiana var. gratae, Artemisia dracunculus var. dracunculus \&var. persica) showed higher artemisinin in their leaves. No artemisinin was found in all four tissues of Artemisia desertorum.
The overall comparison of artemisinin concentration in individual parts across all species showed that among the flowers, highest artemisinin concentration was found in A. annua $(0.42 \pm 0.03 \%)$, followed by $A$. bushriences $(0.34 \pm 0.02 \%)$, and $A$. roxburghiana var roxburghiana $(0.23 \pm 0.01 \%)$, as shown in Figure 3. Among leaves, the

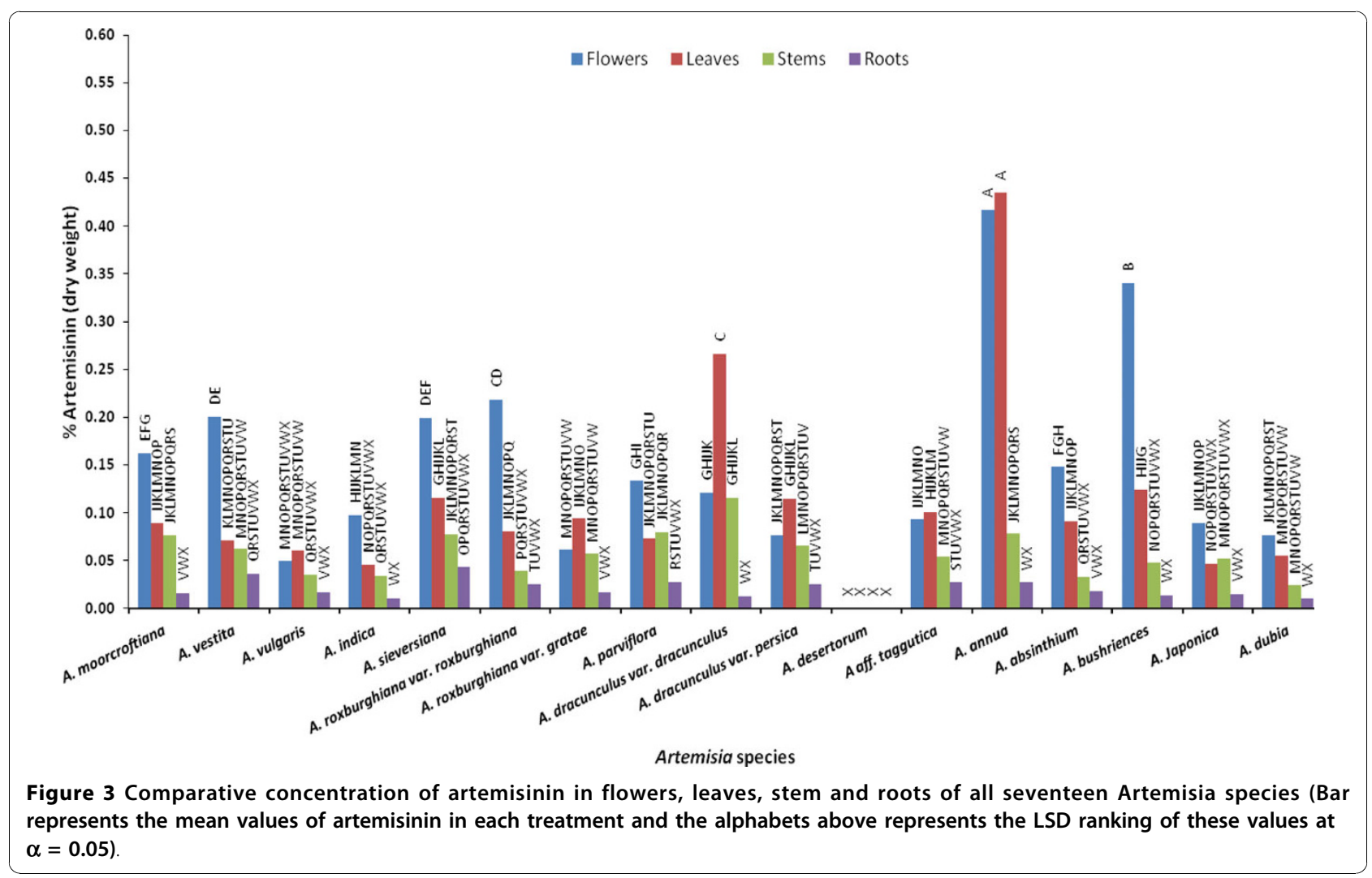




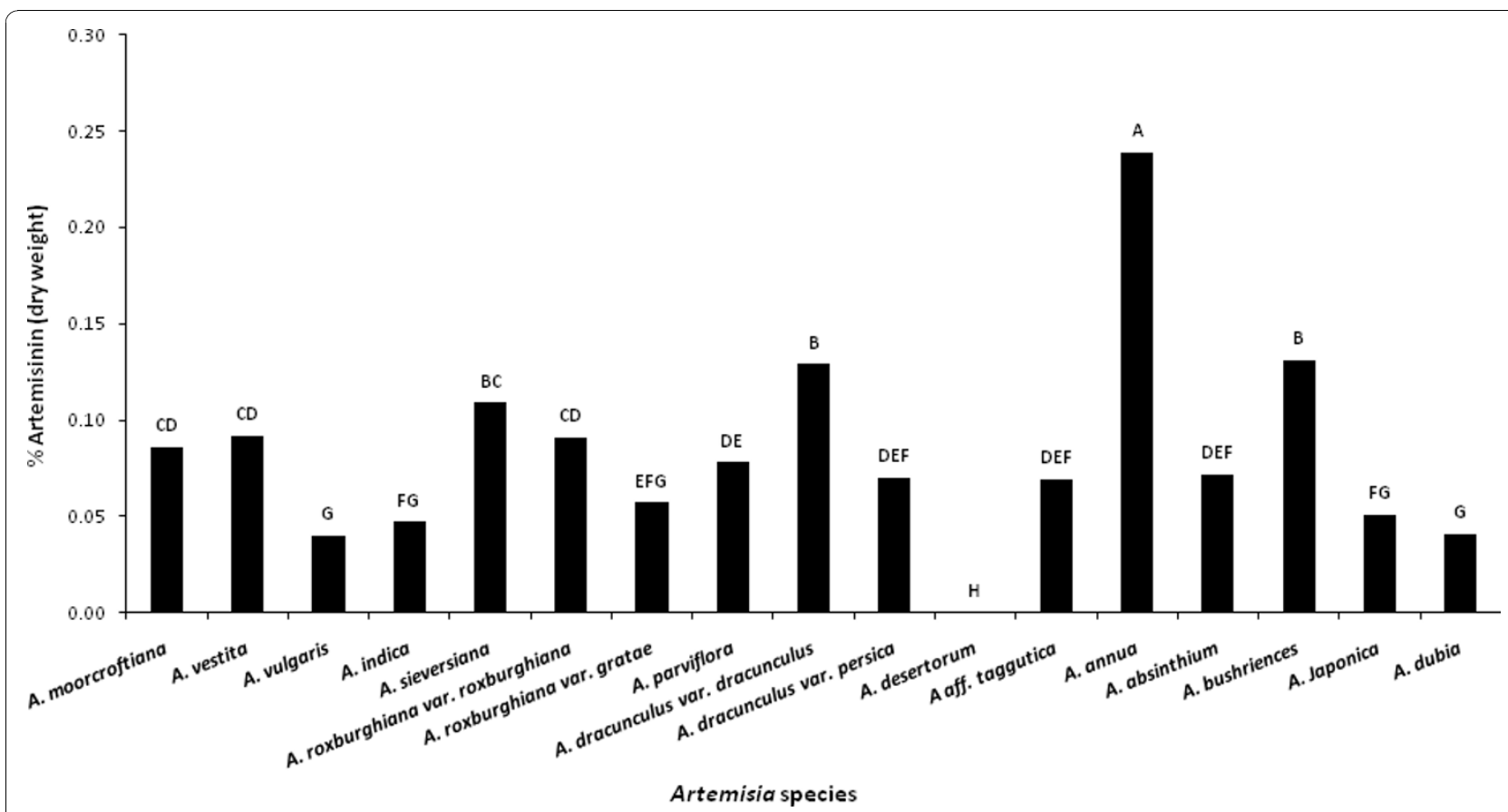

Figure 4 Comparison of whole plant parts (flowers, leaves, stem and roots) artemisinin concentration among all seventeen Artemisia species (Bar represents the mean values of artemisinin in each treatment and the alphabets above represents the LSD ranking of these values at $\alpha=0.05$ ).

highest artemisinin was found in $A$. annua $(0.44 \pm 0.03 \%)$, followed by $A$. dracunculus var dracunculus $(0.27 \pm 0 \%)$. In stems, the highest artemisinin was in $A$. dracunculus var dracunculus $(0.12 \pm 0.01 \%)$ followed by A. parviflora, A. moorcroftiana, A. sieversiana and A. annua $(0.8 \pm 0 \%)$. Among roots, the highest artemisinin concentration was found in $A$. vestita and $A$. sieversiana $(0.04 \pm 0 \%)$. The current study reports artemisinin in 12 species of Artemisia for the first time. Table 2 lists all Artemisia species which have been studied with respect to artemisinin yield up to now. It can be anticipated, however, that some variation in artemisinin concentration in previously reported work may be possible due to differences in methods of artemisinin extraction.

\section{Discussion}

Many natural products in plants are multifunctional molecules that protect them from infections of bacteria, viruses, and other microorganisms, or from herbivores such as insects, worms, and mammals [35]. Artemisinin has been shown to be active against diverse plant pathogenic fungi including Gaeumannomyces graminis var. tritici, Rhizoctonia cerealis, Gerlachia nivalis, and Verticillium dahliae [36].

Dried Artemisia parts have been used in many studies [37-39] for qualitative as well as quantitative analysis of artemisinin; artemisinin analysis in current study was also carried out on dried parts. Artemisinin has previously been extracted with $n$-hexane [38], toluene [40], chloroform [41] and petroleum ether [42] and with extraction times ranging from a few minutes [43] to several hours [44]. In current study, extraction of artemisinin was carried out in toluene, as it is currently the most widely used solvent $[30,34,39]$.

Many analytical procedures to identify and quantify artemisinin have been developed during the last three decades. These include thin layer chromatography (TLC) [42], high performance liquid chromatography with UV detection (HPLC-UV) [45,46], gas chromatography coupled to mass spectrometry (GC-MS) [41], capillary electrophoresis coupled to UV detector (CE-UV) [47] and enzyme-linked immunosorbent assay (ELIZA) [48]. Artemisinin analysis in this study was carried out by using HPLC-UV method for rapid, accurate and cost effective detection and quantification of artemisinin. This is currently the most commonly used method for artemisinin assays $[34,39,45]$.

A prominent feature of current research work was to screen out maximum available Artemisia species for the presence of artemisinin by using same procedure of extraction (using toluene), same equipment for analysis (HPLC-UV) and same type of plant tissues (dried plant tissues), in four different parts (flowers, leaves, stems, roots) of plants growing at same stage (flowering stage).

Comparison of artemisinin yield at different stages of plant development shows a positive correlation between 
Table 2 Summary of previous reports from different parts of the world showing percentage of artemisinin in different parts of Artemisia species

\begin{tabular}{|c|c|c|c|c|c|}
\hline S. No. & Artemisia species & Part used & Artemisinin Percentage & Country of origin & Reference \\
\hline 1 & A. annua & Leaves & 0.60 & China & [64] \\
\hline 2 & A. annua & Leaves & 0.10 & Argentina & [61] \\
\hline 3 & A. annua & Leaves & 0.02 & Germany & [49] \\
\hline 4 & A. annua & Leaves & $0.79,0.14$ & China & [44] \\
\hline 5 & A. annua & Leaves & 0.21 & USA & [44] \\
\hline 6 & A. annua & leaves & 0.24 & Spain & [53] \\
\hline 7 & A. annua & Leaves & 1.07 & China & [53] \\
\hline 8 & A. annua & Leaves & 1.38 & Switzerland & {$[53]$} \\
\hline 9 & A. annua & Leaves & 0.86 & Vietnam & {$[65]$} \\
\hline 10 & A. annua & Leaves & 0.46 & Vietnam & {$[66]$} \\
\hline 11 & A. annua & Leaves & 0.52 & Netherlands & {$[66]$} \\
\hline 12 & A. cina & Shoots & 0.0006 & Indonesia & {$[27]$} \\
\hline 13 & A. apiacea & Leaves & Not shown & China & {$[26]$} \\
\hline 14 & A. lancea & Leaves & Not shown & China & {$[26]$} \\
\hline 15 & A. sieberi. & Aerial Parts & 0.2 & Iran & {$[28]$} \\
\hline 16 & A. absinthium & Leaves & 0.022 & Pakistan & {$[29]$} \\
\hline 17 & A. dubia & Roots & Variable & Pakistan & [30] \\
\hline 18 & A. indica & Roots & Variable & Pakistan & [30] \\
\hline
\end{tabular}

the plant age and artemisinin yield [49]. For A. апnиa, the highest artemisinin concentration has been reported in leaves and flowers during full bloom stage, in comparison to the pre- and post-flowering stages [50]. Some reports show $0.54 \%$ and $0.45 \%$ artemisinin concentration in leaves and flowers of A. annua respectively [50]; concentration ranging from $0.01 \%$ to $0.80 \%$ in leaves and flowers of $A$. annua [51], $0.46 \%$ and $0.52 \%$ in leaves of $A$. annua from Vietnam and Netherlands respectively [52], $0.24 \%$ in A. annua dry leaves [53], while $0.42 \%$ in some individual U.S. strains at the full flowering stage [54]. The present findings suggest similar results; Figure 3 shows that the highest and almost equal artemisinin concentration was detected in leaves $(0.44 \pm 0.03 \%)$ and flowers $(0.42 \pm 0.03 \%)$ of $A$. annua. An important finding is the presence of appreciable concentration of artemisinin in either leaves or flowers of six Artemisia species including $A$. vestita, A. sieversiana, A. roxburghiana var roxburghiana, A. dracunculus var dracunculus, A. annua and $A$. bushriences, in the range from $0.20 \%$ to $0.44 \%$ (Figure 3$)$. Some reports had previously shown the presence of artemisinin in Artemisia species other than A. annua, but the artemisinin concentrations were either negligible [27] or low [28], as shown in Table 2.

Flowers and leaves of ten Artemisia species including A. moorcroftiana, A. vulgaris, A. indica, A. roxburghiana var gratae, $A$. parviflora, $A$. dracunculus var persica, $A$. aff tangutica, A. absinthium, A. japonica, and A. dubia were found to contain artemisinin in the range of $0.05 \%$ to $0.15 \%$, as presented in Figure 3. Six of these ten species contain more artemisinin in flowers than that in leaves, which is in agreement with a prior study [55], reporting that artemisinin content of inflorescence in bud stage was not higher than in leaves, but artemisinin in flowers at full bloom was 4 to 11 fold higher than in leaves of $A$. annua. Generally, leaves are much more abundant than flowers in species studied, and leaves can provide more artemisinin on average per plant than flowers. According to a report [44] leaves contribute the major dry matter for artemisinin extraction, and $89 \%$ of total plant artemisinin comes from leaves. This is the reason of commercial use of $A$. annua leaves for extraction of artemisinin in China, Vietnam and other countries of the world [56]. Furthermore, upper portion of leaves or aerial parts of $A$. annua yield more artemisinin than lower portion of leaves.

Artemisinin concentration in roots of all Artemisia species in current study was non-significant (Figure 3). These findings are in agreement with previous studies $[34,57]$ showing very low artemisinin concentration $(0.003 \%)$ in the roots of A. аnnua. Artemisinin was not found in roots of $A$. аnnua in some studies [41,58,59]. The overall results in the current study suggest presence of high artemisinin concentration in either flowers or leaves and low or zero artemisinin concentration in stems and roots (Figure 3), which is in congruence with a previous report [44], showing artemisinin mostly in leaves and inflorescence of $A$. апnиa, while low levels in stem and none in the roots (Table 2).

Artemisinin is synthesized in specialized capitate glandular trichomes of A. annua [60]. Another study [43] shows that artemisinin is stored in sub-cuticular space of capitate glandular trichomes of Artemisia 
species. Artemisinin accumulates in flowers, leaves, young green stems, buds and seeds where glandular trichomes are present $[61,62]$. Artemisinin and the characteristic aroma of Artemisia plants were absent in foliar tissues of a biotype of $A$. annua lacking glandular trichomes; no ultra-structural differences were found in the mesophyll cells of above biotype with normal biotypes [60]. The current study was focused on flowers, leaves, stems and roots of Artemisia species. Artemisinin concentration in these tissues correlated with the glandular trichome studies of $A$. annua. The association of peak artemisinin with flowering is related to the abundance of glandular trichomes in inflorescence, particularly florets and receptacle [57]. Absence of trichomes and artemisinin could be due to different genetic and environmental factors. Genetic variations have been reported for the plants that retain glands, but lack artemisinin [63]. A recent publication of the genetic map of $A$. annua identifying loci which affect artemisinin production [2] will foster future research into Artemisia genomics.

\section{Conclusion}

This study reported potential new plant sources of artemisinin, in addition to A. annua. These Artemisia species are abundant in distribution in northern Pakistan. The description of their full geographic distribution is beyond the scope of this study. Some of these species yield comparable amounts of artemisinin to that of A. annua (Table 2), and can be screened further for commercial extraction on artemisinin, although most of these are being used as folk therapeutic plants for various purposes [32].

\section{Acknowledgements \\ The current study was funded by a research grants from the Higher Education Commission, Government of Pakistan. Authors are thankful to Peter J. Matthews of National Museum of Ethnology, Osaka, Japan, and Arsala Mansoor, Department of Biochemistry, Bolan Medical College, Quetta, Pakistan, for critical review and suggestions during the preparation of this manuscript. Authors are thankful to Robin Atherton at Allan Wilson Centre for Molecular Ecology and Evolution, Massey University, New Zealand for proofreading this manuscript for correct English usage.}

\section{Author details}

'Department of Biochemistry, Quaid-i-Azam University, Islamabad, Pakistan. ${ }^{2}$ Department of Plant Sciences, Quaid-i-Azam University, Islamabad, Pakistan. ${ }^{3}$ Department of Pharmaceutical Sciences, COMSATS Institute of Information Technology, Abbottabad, Pakistan. ${ }^{4}$ Institute of Molecular Biosciences, Massey University, Palmerston North, New Zealand.

\section{Authors' contributions}

AM, IA and WA contributed in geographical survey, plant collection and processing; AM and RAQ carried out species identification; AM and MFA carried out HPLC assays; AM, IH and BM contributed in results analysis and study design; AM, IA and BM prepared the manuscript, BM supervised the study. All authors read and approved the final manuscript.

\section{Competing interests}

The authors declare that they have no competing interests.

Received: 23 September 2010 Accepted: 4 November 2010 Published: 4 November 2010

\section{References}

1. Enserink M: Epidemology: Lower malaria numbers reflect better estimates and a glimmer of hope. Science 2008, 321:1620.

2. Graham IA, Besser K, Blumer S, Branigan CA, Czechowski T, Elias L, Guterman I, Harvey D, Isaac PG, Khan AM, Larson TR, Li Y, Pawson T, Penfield T, Rae AM, Rathbone DA, Reid S, Ross J, Smallwood MF, Segura V, Townsend T, Vyas D, Winzer T, Bowles D: The genetic map of Artemisia annua $\mathrm{L}$. identifies loci affecting yield of the antimalarial drug artemisinin. Science 2010, 327:328-331.

3. WHO: Malaria. World Health Organization Fact Sheet 942010.

4. WHO: Progress towards the health-related Millennium Development Goals. World Health Organization Fact Sheet 2902010.

5. Mutabingwa TK: Artemisinin-based combination therapies (ACTS): Best hope for malaria treatment but inaccessible to the needy! Acta Trop 2005, 95:305-315.

6. Li J, Zhou B: Biological actions of artemisinin: Insights from medicinal chemistry studies. Molecules 2010, 15:1378-1397.

7. Sen R, Bandyopadhyay S, Dutta A, Mandal G, Ganguly S, Saha P, Chatterjee M: Artemisinin triggers induction of cell-cycle arrest and apoptosis in Leishmania donovani promastigotes. J Med Microbiol 2007, 56:1213-1218.

8. Utzinger J, Xiao SH, Tanner M, Keiser J: Artemisinins for schistosomiasis and beyond. Curr Opin Investig Drugs 2007, 8:105-116.

9. Dunay IR, Chan WC, Haynes RK, Sibley LD: Artemisone and artemiside control acute and reactivated toxoplasmosis in a murine model. Antimicrob Agents Chemother 2009, 53:4450-4456.

10. Nibret E, Wink M: Volatile components of fourEthiopian Artemisia species extracts and their in vitro antitrypanosomal and cytotoxic activities. Phytomedicine 2010, 17:369-374.

11. Romero MR, Serrano MA, Vallejo M, Efferth T, Alvarez M, Marin JJG: Antiviral effect of artemisinin from Artemisia annua against a model member of the Flaviviridae family, the Bovine Viral Diarrhoea Virus (BVDV). Planta Med 2006, 72:1169-1174.

12. Romero MR, Efferth T, Serrano MA, Castano B, Macias RIR, Briz O, Marin JJG: Effect of artemisinin/artesunate as inhibitors of hepatitis $B$ virus production in an "in vitro" replicative system. Antiviral Res 2005, 68:75-83.

13. Efferth T, Dunstan $H$, Sauerbrey A, Miyachi H, Chitambar CR: The antimalarial artesunate is also active against cancer. Int J Oncol 2001, 18:767-773.

14. Efferth $T$, Marschall $M$, Wang $X$, Huong SM, Hauber I, Olbrich A, Kronschnabl M, Stamminger T, Huang ES: Antiviral activity of artesunate towards wild-type, recombinant, and ganciclovir-resistant human cytomegaloviruses. J Mol Med 2002, 80:233-242.

15. Sadava D, Phillips T, Lin C, Kane SE: Transferrin overcomes drug resistance to artemisinin in human small-cell lung carcinoma cells. Cancer Lett 2002, 179:151-156.

16. Stiles LH, Leather GR, Chen PK: Effects of two sesquiterpene lactones isolated from Artemisia annua on physiology of Lemna minor. J Chem Ecol 1994, 20:969-978.

17. Dellicour S, Hall S, Chandramohan D, Greenwood BD: The safety of artemisinins during pregnancy: a pressing question. Malar J 2007, 6:15.

18. Efferth $T$, Kaina B: Toxicity of the antimalarial artemisinin and its dervatives. Crit Rev Toxicol 2010, 40:405-421.

19. Anonymous: The Global Malaria Action Plan. REPORT of the 2008 Artemisinin Enterprise Conference October 8-10: 2008; York, UK 2008.

20. Arrow KJ, Panosian CB, Gelband H: Saving Lives, Buying Time: Economics of Malaria Drugs in an Age of Resistance. Washington DC: National Academy of Sciences; 2004

21. Chang MCY, Eachus RA, Trieu W, Ro D-K, Keasling JD: Engineering Escherichia coli for production of functionalized terpenoids using plant P450s. Nat Chem Biol 2007, 3:274-277. 
22. Newman JD, Marshall J, Chang M, Nowroozi F, Paradise E, Pitera D, Newman KL, Keasling JD: High-level production of amorpha-4,11-diene in a two-phase partitioning bioreactor of metabolically engineered Escherichia coli. Biotechnol Bioeng 2006, 95:684-691.

23. Ro DK, Paradise EM, Ouellet M, Fisher KJ, Newman KL, Ndungu JM, Ho KA, Eachus RA, Ham TS, Kirby J, Chang MCY, Withers ST, Shiba Y, Sarpong R, Keasling JD: Production of the antimalarial drug precursor artemisinic acid in engineered yeast. Nature 2006, 440:940-943.

24. Zeng QP, Qiu F, Yuan L: Production of artemisinin by geneticallymodified microbes. Biotechnol Lett 2008, 30:581-592.

25. Covello PS: Making artemisinin. Phytochemistry 2008, 69:2881-2885

26. Hsu E: The history of qing hao in the Chinese materia medica. Trans $R$ Soc Trop Med Hyg 2006, 100:505-508.

27. Aryanti, Bintang M, Ermayanti TM, Mariska I: Production of antileukemic agent in untransformed and transformed root cultures of Artemisia cina. Annales Bogorienses 2001, 8:11-16.

28. Arab HA, Rahbari S, Rassouli A, Moslemi MH, Khosravirad FDA Determination of artemisinin in Artemisia sieberi and anticoccidial effects of the plant extract in broiler chickens. Trop Anim Health Prod 2006, 38:497-503.

29. Zia M, Abdul M, Chaudhary MF: Effect of growth regulators and amino acids on artemisinin production in the callus of Artemisia absinthium. Pak J Bot 2007, 39:799-805.

30. Mannan A, Shaheen N, Arshad W, Qureshi RA, Zia M, Mirza B: Hairy roots induction and artemisinin analysis in Artemisia dubia and Artemisia indica. Afr J Biotechnol 2008, 7:3288-3292.

31. Ghafoor A: Asteraceae. In Flora of Pakistan. Volume 207. Edited by: Ali S, Qaiser M. Missouri Botanical Garden Press; 2002.

32. Ashraf M, Hayat MQ, Jabeen S, Shaheen N, Khan MA, Yasmin G: Artemisia L. species recognized by the local community of northern areas of Pakistan as folk therapeutic plants. J Med Plants Res 2010, 4:112-119.

33. Mannan A: Determination of artemisinin content of various Artemisia species of Pakistan and its enhancement in Artemisia annua. Islamabad: Quaid-i-Azam University; 2009.

34. Kim Y, Wyslouzil BE, Weathers PJ: A comparative study of mist and bubble column reactors in the in vitro production of artemisinin. Plant Cell Rep 2001, 20:451-455.

35. Efferth T: Artemisinin: A versatile weapon in traditional Chinese medicine. Herbal Drugs: Ethnomedicine to Modern Medicine Berlin Heidelberg: Springer-Verlag; 2009, 173-194

36. Tang $H Q, H u J$, Yang $L$, Tan RX: Terpenoids and flavonoids from Artemisia species. Planta Med 2000, 66:391-393.

37. Delabays N, Simonnet $X$, Gaudin MDAD: The genetics of artemisinin content in Artemisia annua L. and the breeding of high yielding cultivars. Curr Med Chem 2001, 8:1795-1801.

38. Elsohly HN, Croom EM, Elsohly MADAJ: Analysis of the antimalarial sesquiterpene artemisinin in Artemisia annua by high-performance liquid-chromatography (HPLC) with postcolumn derivatization and ultraviolet detection. Pharm Res 1987, 4:258-260.

39. Towler MJ, Weathers PJ: Evidence of artemisinin production from IPP stemming from both the mevalonate and the nonmevalonate pathways. Plant Cell Rep 2007, 26:2129-2136.

40. Laughlin JC: Agricultural production of artemisinin - a review. Meeting on Artemisinin: Apr 25-27 1993; Worcestershire, England 1993, 21-22.

41. Woerdenbag HJ, Pras N, Bos R, Visser JF, Hendriks H, Malingre TM: Analysis of artemisinin and related sesquiterpenoids from Artemisia annua $\mathrm{L}$ by combined gas-chromatography mass-spectrometry. Phytochem Anal 1991, 2:215-219.

42. Klayman DL, Lin AJ, Acton N, Scovill JP, Hoch JM, Milhous WK, Theoharides AD: Isolation of artemisinin (qinghaosu) from Artemisia annua growing in the United States. J Nat Prod 1984, 47:715-717.

43. Duke MV, Paul RN, Elsohly HN, Sturtz G, Duke SO: Localization of artemisinin and artemisitene in foliar tissues of glanded and glandless biotypes of Artemisia annua L. Int J Plant Sci 1994, 155:365-372.

44. Charles DJ, Simon JE, Wood KV, Heinstein P: Germplasm variation in artemisinin content of Artemisa annua using an alternative method of artemisinin analysis from crude plant extracts. J Nat Prod 1990, 53:157-160.

45. Lapkin AA, Walker A, Sullivan N, Khambay B, Mlambo B, Chemat S: Development of HPLC analytical protocols for quantification of artemisinin in biomass and extracts. J Pharm Biomed Anal 2009, 49:908-915.

46. Zhao S, Zeng M: Studies on the analysis of qinghaosu by high-pressure liquid chromatograph and spectrometry (HPLC). Planta Med 1985, 51:233-237.

47. Christen P, Veuthey JLDAD: New trends in extraction, identification and quantification of artemisinin and its derivatives. Curr Med Chem 2001, 8:1827-1839

48. Jaziri M, Diallo B, Vanhaelen M, Homes J, Yoshimatsu K, Shimomura KDAJ: Immunodetection of artemisinin in Artemisia annua cultivated in hydroponic conditions. Phytochemistry 1993, 33:821-826.

49. Singh A, Vishwakarma RA, Husain A: Evaluation of Artemisia annua strains for higher artemisinin production. Planta Med 1988, 475-477.

50. Baraldi R, Isacchi B, Predieri S, Marconi G, Vincieri FF, Bilia ARDAM-JDOjb: Distribution of artemisinin and bioactive flavonoids from Artemisia annua L. during plant growth. Biochem Syst Ecol 2008, 36:340-348.

51. Abdin MZ, Israr M, Rehman RU, Jain SKDAA: Artemisinin, a novel antimalarial drug: Biochemical and molecular approaches for enhanced production. Planta Med 2003, 69:289-299.

52. Wallaart TE, Pras N, Beekman AC, Quax WJ: Seasonal variation of artemisinin and its biosynthetic precursors in plants of Artemisia annua of different geographical origin: Proof for the existence of chemotypes. Planta Med 2000, 66:57-62.

53. Delabays N, Collet G, Benakis A: Selection and breeding for high artemisinin (Qinghaosu) yielding strains of Artemisia annua. Acta Hort 1993, 330:203-207

54. Zhou $W, X u X$ : The structures, reactions and synthesis of arteannuin (qinghaosu) and related compounds. In Studies in Natural Products Chemistry. Volume 30. Edited by: Rahman A. New York: Elsevier; 1988:495-527.

55. Ferreira JFS, Simon JE, Janick J: Relationship of artemisinin content of tissue-cultured, greenhouse-grown, and field-grown plants of Artemisia annua. Planta Med 1995, 61:351-355.

56. Bilia AR, de Malgalhaes PM, Bergonzi MC, Vincieri FFDA: Simultaneous analysis of artemisinin and flavonoids of several extracts of Artemisia annua L. obtained from a commercial sample and a selected cultivar. Phytomedicine 2006, 13:487-493.

57. Ferreira JFS, Janick J: Roots as an enhancing factor for the production of artemisinin in shoot cultures of Artemisia annua. Plant Cell Tiss Org Cult 1996, 44:211-217

58. Gulati A, Bharel S, Jain SK, Abdin MZ, Srivastava PS: In vitro micropropagation and flowering in Artemisia annua. J Plant Biochem Biotechnol 1996, 5:31-35.

59. Kim N, Kim S: Biosynthesis of artemisinin from 11,12-dihydroarteannuic acid. J Korian Agri Chem Soc 1992, 35:106-109.

60. Duke SO, Paul RN: Development and fine-structure of the glandular trichomes of Artemisia annua L. Int J Plant Sci 1993, 154:107-118.

61. Acton N, Klayman DL, Rollman IJ: Reductive electrochemical HPLC assay for artemisinin (qinghaosu). Planta Med 1985, 51:445-446.

62. Liersch R, Soicke H, Stehr C, Tullner HU: Formation of artemisinin in Artemisia annua during one vegetation period. Planta Med 1986, 52:387-390.

63. Nielsen MT, Akers CP, Jarlfors UE, Wagner GJ, Berger S: Comparative ultrastructural features of secreting and nonsecreting glandular trichomes of 2 genotypes of Nicotiana tabacum L. Bot Gaz 1991, 152:13-22.

64. Liu J, Ni M, Fan J, Tu Y, Wu Z, Qu Y, Chou M: Structure and reactions of artemisinin. Acta Chim Sin 1979, 37:129-143

65. Woerdenbag H, Pras N, Chan N, Bang B, Ros R, Von U, Van Y, Boi N, Batterman $S$, Lugt $C$ : Artemisinin related sesquiterpenes and essential oil in Artemisia annua during a vegetation period in Vietnam. Planta Med 1994, 60:272-275.

66. Wallaart T, Pras N, Quax W: Seasonal variation of artemisinin and its biosynthetic precursors in tetraploid Artemisia annua plants compared with the diploid wild type. Planta Med 1999, 65:723-728.

doi:10.1186/1475-2875-9-310

Cite this article as: Mannan et al: Survey of artemisinin production by diverse Artemisia species in northern Pakistan. Malaria Journal 2010 9:310. 